\title{
Rethinking the Concept of Hybrid Warfare within the Framework of Semiotic Anthropology
}

\begin{abstract}
The term psychological operations, viewed in the context of security sciences as one of the fundamental methods of contemporary hybrid warfare is commonly described as the use of non-military means such as information campaigns, subversive activities, indirect strategic communication and propaganda in attempts to achieve certain strategic goals. However, I will argue that by describing these activities as psychological, we risk losing sight of their cultural aspects, namely the fact that they are directed at and conducted within a specific cultural context. By placing the concept of hybrid warfare within the framework of semiotic anthropology, I will show how the activities traditionally viewed by the security experts as psychological in nature are actually directly linked to shared cultural meanings, values, motivations, worldviews and cultural and subcultural identities. I will argue that hybrid warfare, in its essence, can be viewed as a conflict resulting from the simultaneous presence of competing interpretations of social reality within one sociocultural context.
\end{abstract}

Keywords: Hybrid warfare, political warfare, PSYOPS, semiotic anthropology, cultural communication.

\section{Introduction}

Hybrid warfare is not a new concept - ever since the days of the Cold War, the term "political warfare" has been used to describe "attempts to win the "hearts and minds' of the population" (Hoffman 2014) and just a quick look at contemporary literature on the topic written by the security and military experts seems to indicate that there is still much confusion about the question of whether hybrid warfare is something new or something that has always been present as a part of 
human political activity (Obućina 2016; Korybko 2015; Newson 2014). What is undoubtedly new, however, is the prominent place hybrid warfare and the activities associated with it currently have in the media narratives and the public discourse.

The public's interest for this question seems to have peaked in the early 2014 following the events of "Euromaidan" in Ukraine and the subsequent change in the status of Crimea. On one hand, the Russian side accused the new Ukrainian government of radical nationalism, discrimination, violence and other actions that violate not only the international law, but also the fundamentals of Ukrainian constitution, describing the events of "Euromaidan" as orchestrated from the outside and directed against the Russian Federation. ${ }^{1}$ On the other hand, insisting that "Euromaidan" is authentic popular movement, ${ }^{2}$ a number of political actors who opposed this stance focused instead on accusing Russia of military occupation of the peninsula, describing the subsequent referendum on the status of Crimea as illegitimate and the change in its status as annexation ${ }^{3}$, as opposed to Russia's insistence on reunification.

As the violence throughout Crimea decreased and eventually disappeared following the peninsula's integration in the Russian Federation, it seemed that the conflict between Russia and those countries that vehemently opposed the change of status of the peninsula became increasingly more related to the question of whether the said status change should be thought of as annexation or reunification. This same war of words is still continuing, almost five years later, not only through the media narratives and official statements of both sides to the conflict, but also through the international sanctions imposed against Russia under the pretext of unlawful annexation. ${ }^{4}$ Needless to say, the Russian side considers the sanctions to be illegitimate, refusing to give in to what it perceives as unlawful pressure aimed at weakening its international position, stating, on the contrary, that Crimea question is closed for good. ${ }^{5}$ Both sides, as well as numerous analysts, frequently described the ensuing conflict on the international arena as a hybrid or sometimes media war (Kofman, McDermot 2015; Kofman, Rojansky 2015) due to the fact that it was largely limited to confrontations in the media and public relations sphere.

With this in mind, it comes as no surprise that the main "combatants" in this conflict were government officials of various levels, foreign ministry and State

${ }^{1}$ http://www.mid.ru/en/foreign_policy/news/-/asset_publisher/cKNonkJE02Bw/content/ id/671172 (access: 16.02.2019).

2 https://www.theguardian.com/commentisfree/2014/apr/30/russia-ukraine-war-kiev-conflict (access: 16.02.2019).

3 https://www.nato.int/cps/en/natohq/news_118114.htm (access: 16.02.2019).

${ }^{4}$ https://themoscowtimes.com/articles/g7-leaders-agree-to-prolong-anti-russian-sanctions-53043 (access: 16.02.2019).

5 https://www.rt.com/news/377387-russia-crimea-ukraine-trump/ (access: 16.02.2019). 
Department spokespersons, but also certain media outlets which strongly support one or the other interpretation of the Crimea crisis. The arena in which this conflict is taking place is mostly limited to media space, with different press conferences, international meetings and regular announcements by state officials all being used as opportunities for a certain interpretation of the crisis to be communicated to the general public and global audiences. However, once those ideas reached the general public, they changed in various ways among various groups.

While the opposition between ideas of annexation and reunification, occupation and liberation do form what we can the main axis of this conflict, these interpretations are directly tied to a number of different ideas, concepts or events that transcend the crisis as such to a certain extent. For example, while the events of "Euromaidan" are absolutely crucial to Russian understanding of the following Crimea crisis, ${ }^{6}$ NATO officials, on the other hand, find little reason to discuss the change of power in Kiev in the context of Crimea crisis, explaining the events of "Euromaidan" simply as expression of people of Ukraine "in favour of Democracy, unity and European integration", 7 that has little to do with what is perceived as Russia's aggressive policies, with the notable exception of it marking yet another blow to Russian domination in the post-Soviet space. ${ }^{8}$

The two narratives briefly mentioned here are just some of the many different interpretations of the Crimea crisis that have been put forward by different individuals, groups, media outlets and government officials. However, what makes these two interpretations stand out among the others is the fact that both of them are put forward by influential and relevant political actors and both of them aim to transcend the crisis, functioning as a much larger statement about the current state of international relations and the current positions and stances of some of the most influential and powerful actors in the international arena. The difference between Russian response to American "purposeful destabilisation of Ukraine" as well as to the "criminal and provocative actions" by the "ultra-nationalists supported by Kiev" 10 and the Russian "illegal annexation" of Crimea ${ }^{11}$ under pretext that has already been utilised by Hitler in 1930s in the case of Czechoslovakia ${ }^{12}$ is so stark that it is hard to even imagine a compromise between the two interpretations of the same event.

6 https://sputniknews.com/russia/201412181015985110/ (access: 16.02.2019).

7 https://www.nato.int/cps/en/natohq/opinions_115313.htm (access: 16.02.2019).

8 https://foreignpolicy.com/2014/03/18/wheres-natos-strong-response-to-russias-invasion-of-crimea/ (access: 17.02.2019).

9 http://tass.com/world/800230 (access: 13.02.2019).

${ }^{10} \mathrm{https} / /$ www.usatoday.com/story/theoval/2014/03/02/obama-russia-putin-ukraine-crimea/ 5944265/ (access:16.02.2019).

${ }^{11} \mathrm{https} / /$ www.usatoday.com/story/news/politics/2014/03/20/obama-ukraine-statement/ 6647657/ (access: 16.02.2019).

${ }^{12}$ https://www.theguardian.com/world/2014/mar/06/hillary-clinton-says-vladimir-putins-crimea-occupation-echoes-hitler (access: 14.02.2019). 
However, both of these interpretations require the international community to act, and the machinery of international law to be put into motion. Both of them have proven to be highly efficient forms of political pressure and both of them offer a worldview that is exemplified in the Crimea crisis, but which transcends it to a significant degree. When Jean Baudrillard wrote about the Gulf War, he concluded that unlike wars that preceded it and that had political aims involving domination or conquest, what was at stake in the case of the Gulf War was "war itself: its status, its meaning, its future" (Baudrillard 1995: 32). In the same manner, the importance of the Crimea crisis is related not to, for example, strategic position of the peninsula, but the meaning of the ensuing situation and its implication for the current status and future of international relations. The convergence of important political actors and their interests in Crimea made the whole crisis a perfect expressive act - the one that has all the potential to tell us what kind of world are we living in, what are its dangers, who are the enemies that we should be afraid of and who are the allies that we can rely upon.

So, for example, Russia's activity and military presence in Crimea are presented by Russian officials not only as legitimate, ${ }^{13}$ but also moral, honourable and humane ${ }^{14}$ - due to the fact that these activities are aimed at protecting the civilian population from the persecution by the extremists who came to power in Ukraine through the unlawful use of force, as said by Russian president Vladimir Putin himself. ${ }^{15}$ Likewise, the sanctions imposed against Russia by a number of countries are also perfectly justified from the point of view of those countries and their officials, due to the fact that they are aimed at punishing unlawful occupation of the territory, again, as said by then-president of the US Barack Obama ${ }^{16}$ and fraudulent political process exemplified by a referendum organised under military occupation. ${ }^{17}$

For both sides, the war of words and the war of ideas take the centre stage, the respective interpretations of both sides are complemented by actions which are in line with those interpretations and which support them, both sides are trying to convince the international community and global audience that their interpretation is correct, while the opposing one is not, neither of them is willing to compromise with the other as exemplified by a line of failed meetings between

${ }^{13}$ https://sputniknews.com/politics/201605041039061827-maria-zakharova-crimea-russia-ukraine/ (access: 16.02.2019).

${ }^{14} \mathrm{https} / / /$ www.rt.com/news/putin-statement-ukraine-russia-743/ (access: 13.02.2019).

15 https://www.usatoday.com/story/theoval/2014/03/02/obama-russia-putin-ukraine-crimea/ 5944265/ (access: 16.02.2019).

${ }^{16} \mathrm{http}: / /$ time.com/13902/barack-obama-ukraine-russia/ (access: 14.02.2019).

17 https://www.usatoday.com/story/news/politics/2014/03/20/obama-ukraine-statement/ 6647657/ (access: 16.02.2019). 
Russian foreign minister Sergey Lavrov and, at the time, his American counterpart, former secretary of state, John Carry. ${ }^{18}$

By analysing these two opposing interpretations of the Crimea crisis put forward by Russian and NATO officials, as well as the ways that they shape and direct actions of political actors, but also play on the emotions of the general public, I will show that the concept of hybrid warfare can be further elaborated and better understood once we view strategic communication as essentially cultural communication. I will argue that the term "psychological operations" commonly used by the security experts can be replaced with a much more precise definition of "cultural operations", allowing us to define hybrid warfare as a cultural conflict resulting from the simultaneous presence of competing interpretations of social reality within one sociocultural context.

\section{Towards understanding of hybrid warfare}

Most of the security and military experts writing about hybrid threats and hybrid warfare agree that these terms are used to describe "unclear and diffuse conflicts" which cannot fit in the "neat intellectual categories" traditionally used to describe and understand war (Hoffman 2014). Despite this broadest view being widely shared, the consensus on the exact definition of the terms is still lacking. Because of this, our first task is to identify different types of activity that are considered to be examples of hybrid warfare.

However, the complexity and ambiguity of this term are further emphasised by the fact that it has been used to describe numerous very different events and operations - the activities of Al-Qaeda and the Taliban in Afghanistan (Obućina 2016), the deployment of automated underwater probes in the South China Sea (Burgers, Romaniuk 2016) or the involvement of Russia in the events in eastern Ukraine in 2014, as well as the involvement of the USA in numerous "colour revolutions" across the world (Korybko 2015). Evidently, some of these examples include actual combat operations, while others do not; some of them are undertaken by state actors, while others are employed by various non-state organisations including both legally operating NGOs and internationally banned terrorist organisations. This wide array of actions classified as hybrid warfare undertaken by very different actors seem to indicate that this term is more a broad category, encompassing different forms of activities than a precisely defined concept referring to a specific phenomenon.

Robert Newson's understanding of hybrid warfare perfectly exemplifies these difficulties in trying to define the term with more precision. Failing to find a com-

${ }^{18} \mathrm{https} / / /$ www.reuters.com/article/us-ukraine-crisis-russia-lavrov/russias-lavrov-says-no-agreement-with-kerry-on-ukraine-report-idUSBREA2515V20140306 (access: 18.02.2019). 
mon denominator for all the diverse activities considered, he simply argues that hybrid warfare can be understood as use of "unconventional, irregular and asymmetric means", including the continued manipulation of political and ideological conflicts, as well as the combination of special operations and conventional military units, intelligence agencies, "political provocateurs", media, economic deterrence, cyber-attacks and other activities (Newson 2014). While this list certainly underlines some important forms of hybrid warfare, it doesn't bring us closer to understanding the term.

Contrary to him, Andrew Korybko, for example, tries to reduce the complexity of the concept by stating that "colour revolution" and "unconventional warfare" are "two pillars of hybrid warfare" (Korybko 2015: 70) which roughly coincide with his ideas of soft and hard coup d'état (Korybko 2015: 10), but also with the view of contemporary conflicts described in the Russian Military Doctrine as "integrated utilisation of military force and forces and resources of non-military characters", as well as the implementation of information warfare in order to accomplish political goals without the use of military force and in the interest of shaping a favourable response from the international community to the use of military force (Kofman, Rojansky 2015: 2-3).

But this approach is not exclusive to Russian security experts and military officials. In fact, the relevant NATO authorities seem to agree that non-military means of subversive nature now play the leading role in hybrid warfare, with ideal situation being that of the attacking state completely refraining from the use of military force, focusing instead on the "control of the minds of political leadership and the population" of the attacked state using means such as propaganda, psychological operations, deception campaigns or information warfare (Zlatohlávek 2016: 10). Even general James Mattis, the former United States Secretary of Defence with a rich military career both in the US Army and in NATO, pointed out that American military doctrine focuses on psychological and informational aspects of their operations which do not require physical presence of the troops on the ground, but which have to make it possible to communicate certain messages to the population. These operations, according to Mattis, are "the wars of ideas" and the American ideas "have to compete with the enemy's ideas" (Mattis, Hoffman 2005).

With greater focus on the war of ideas and strategic communication, it would seem that the concept of hybrid warfare is coming very close to the preceding Cold War idea of political warfare (Hoffman 2014) which includes the use of all those non-military activities which aim to internalise specific ideas among the population of the state (Korybko 2015: 10,13) and all those operations which are directed against "the political structures, state authorities, state economy or armed forces with the goal of demoralising the population" (Zlatohlávek 2016: 11). This means that hybrid warfare is based on activities which are known among the security and military experts as psychological operations and which are conducted 
in such a way that they will be able to go hand-in-hand with military intervention or other political or economic measures, if necessary.

Psychological operations are the tools that are employed with the goal of convincing individual members of a society to accept the ideology, goals or values of the attacking group (Korybko 2015: 22, 33). They are based on "group psychology" (Korybko 2015: 34) and are conducted through information campaigns of various forms. Of course, the terms communication and information are absolutely essential here - if psychological operations aim to make individuals "internalise" certain ideas, making the impression that they appeared spontaneously, authentically, naturally among the members of a society as Korybko suggests (Korybko 2015: 35), then those ideas must be first communicated to the general public in a certain way - indirectly (Korybko 2015: 29-30), relying strongly on symbolism and cultural meanings in order to be effective.

Of course, this communication doesn't need to take place verbally or through writing (Leach 1976: 9-10). Provided that the message exists, the communication channel through which it is transmitted can be extremely varied. However, what remains absolutely necessary precondition for any successful act of communication is the knowledge of the code used to encode the information on one end of the communication channel and decode it on the other (Žikić 2010:28). This is the fundamental precondition without which the message communicated would be either misunderstood or completely missed on the receiving end. This direct link between cultural knowledge and successful instances of cultural communication further highlights the crucial role of cultural symbolism in what security experts tend to call strategic indirect communication (Korybko 2015: 65).

\section{Competing interpretations of the Crimea crisis: From psychological towards cultural operations}

According to Clifford Geertz, the role of symbolism is even greater than simply enabling the transmission of information from one to the other side of the communication channel - cultural patterns viewed as organised systems of symbols, he argues, are fundamentally shaping human behaviour and human experience (Geertz 2000: 46), being in the very foundation of human social existence and perception of reality. This implies that there is a direct link between culture, behaviour and the interpretation of the social reality. By extension, we can hypothesise that by manipulating cultural meanings in a certain way, it is theoretically possible to influence behaviour, motivations, dispositions or values and shape the worldview of an individual, including his or her interpretation of other events and phenomena.

In line with this, Geertz argues that the pluralism of cultures (or subcultures) in any given context gives rise to pluralism of interpretations of social reality. This, 
of course, does not bring into question the ontological status of certain facts or events, but it does direct the attention of an anthropologist from the idea of objective facts to the interpretations and meanings of those facts. (Geertz 2000: 9, 14) The central question of anthropological analysis then becomes what things that are communicated through certain culturally perceived facts in various sociocultural groups (Geertz 2000: 16, 17). This approach allows us to focus not on any event as such, but on different interpretations of the said event and the way that that interpretation is shaping cultural behaviour of a group or individual.

By drawing a parallel to these ideas, we can say, for the sake of argument, that in the case of Crimea we encounter two reference frames - one Russian and one put forward by the NATO member states who were among the most vocal members of the international community that opposed the change of status of Crimea. Of course, in reality we may encounter many additional perspectives communicated by many different actors, which can in turn bring into question the homogeneity of the narratives and interpretations discussed here. For the sake of simplicity, I suggest focusing on two most dominant and directly opposed narratives - one that focuses on the idea of Crimea's reunification with Russia and one that, on the contrary, focuses on Crimea's annexation by Russia.

These narratives are, of course, based on certain facts that can hardly be brought into question - there is a new government in Kiev and there has been a change in status of Crimea which is now administered by Moscow - the ontological status of these facts is not questioned, in fact, their existence and relevance seem to be the only points about which both sides to the conflict seem to agree. What is questioned and what is in the very essence of the Crimea conflict is the meaning, the interpretations of these facts and most importantly, the implications of those interpretations for both sides' legitimacy and position in the international community. By contesting the right to offer the final, "ultimate" interpretation, both sides use a number of different tools which can, from this perspective, all be viewed as instances of cultural communication focused on, as I will argue, communication of certain worldview that aims to influence and shape the interpretations of the given events.

To begin with the events of the "Euromaidan", it seems they play a crucial role in the interpretation of the Crimea crisis that is put forward by what we can consider an official Russian stance. As high-ranking officials of the Russian Federation said on numerous occasions, official Moscow saw the events of "Euromaidan" as illegitimate, orchestrated from the outside and directed against Russia. ${ }^{19,20}$

The perceived illegitimacy of the new government in Kiev as well as the danger posed to the Russian-speaking population in Crimea and eastern Ukraine by the "radicals in Kiev" ${ }^{21}$ play a crucial role in this interpretation of the Crisis, as it

\footnotetext{
19 http://tass.com/world/800230 (access: 13.02.2019).

20 https://sputniknews.com/russia/201412181015985110/ (access: 16.02.2019).

${ }^{21}$ https://www.rt.com/news/putin-statement-ukraine-russia-743/ (access: 13.02.2019).
} 
allows official Moscow to communicate the message that actions it undertakes are inherently right, both from legal and moral perspective. Various media materials to cast aside any doubts that Crimean referendum wasn't genuine and legal expression of the will of the people of $\mathrm{Crimea}^{22}$ or that the Russian-speaking population on the peninsula wasn't persecuted by the Kiev authorities and various paramilitary groups such as notorious Azov battalion. ${ }^{23}$

On the other hand, those members of the international community that oppose Russian moves in the region pay comparatively little attention to "Euromaidan" and the change of government in Kiev, focusing instead on the Russian activities on Crimea that are interpreted as illegal occupation ${ }^{24}$, invasion ${ }^{25}$ or occupation, implying a serious breach of international law. ${ }^{26}$ Similarly to how official Moscow used perceived illegitimacy of the Kiev authorities to justify their actions, so do NATO officials who spoke out against the change of status of Crimea rely on perceived illegitimacy of Russia's actions in order to portray the Crimea referendum as illegal and void. ${ }^{27}$

Carefully avoiding any direct military confrontation, the conflicted sides took action in various different ways in order to support their respective interpretations. On one hand, a number of NATO and EU members introduced sanctions against Russia due to perceived annexation of the peninsula ${ }^{28}$ claiming that the sanctions were brought into place because of Russian aggression, disrespect of the national borders and international law, with the goal of isolating Russia from the law-abiding members of the international community. ${ }^{29}$ On the other hand, Russia showed little to no interest in discussing the sanctions, claiming that they are themselves illegal as Russia acted well within the norms of international law, unlike those who interfered in the internal affairs of Ukraine ${ }^{30}$ and who continued with illegal actions by introducing unfounded sanctions. ${ }^{31}$

22 https://sputniknews.com/politics/201510291029308926-crimea-moscow-zakharova-fabius/ (access: 16.02.2019).

${ }^{23}$ http://tass.com/russia/792788 (access: 16.02.2019).

${ }^{24} \mathrm{https} / / /$ www.usatoday.com/story/news/world/2014/03/25/ukraine-europe/6863413/ (access: 16.02.2019).

${ }^{25} \mathrm{https} / /$ foreignpolicy.com/2014/03/18/wheres-natos-strong-response-to-russias-invasion-of-crimea/ (access: 17.02.2019).

${ }^{26} \mathrm{https}: / /$ www.nato.int/cps/en/natohq/opinions_115313.htm (access: 16.02.2019).

${ }^{27} \mathrm{https} / /$ www.reuters.com/article/us-ukraine-crisis-nato/nato-says-crimea-referendum-would-break-international-law-idUSBREA2D1NI20140314 (access: 18.02.2019).

${ }_{28} \mathrm{https} / / /$ www.theguardian.com/world/2014/jul/29/economic-sanctions-russia-eu-governments (access: 14.02.2019).

${ }^{29} \mathrm{https} / / /$ www.nato.int/cps/en/natohq/opinions_115313.htm (access: 16.02.2019).

${ }^{30} \mathrm{http} / / /$ www.mid.ru/en/foreign_policy/news/-/asset_publisher/cKNonkJE02Bw/content/id/ 671172 (access: 16.02.2019).

${ }^{31} \mathrm{https} / /$ www.rferl.org/a/medvedev-warns-that-u-s-sanctions-banning-banks-currency-use-would-be-economic-war-/29425557.html (access: 14.02.2019). 
By bringing all these different attitudes, ideas and accusations in a metonymical relation, both sides upped the stakes by communicating the interpretation of not one specific fact, but of a cluster of events and facts related to the actions of both the communicators and of their geopolitical opponents. So, if Crimean referendum was in line with international law, as official Moscow states, then Russia acted well within its right, and those who opposed its moves were wrong not only when it comes to introducing sanctions against Russia, but also in supporting the "Euromaidan" events at first place, as well as the new "extremist" government in Kiev, as Russia views it. In the same manner, if Russia acted illegally on Crimea, as is the official position of NATO, then the referendum is certainly null and void, and the sanctions serve their purpose of "marking" Russia as the side that actually breached the international law. But, by raising the stakes in such a way, the whole conflict became even less related to Crimea and even less concerned with situation on the ground, with the chain of events being interpreted being almost completely reduced to a kind of channel for a conflict of a much broader scope.

I would argue that these two opposed narratives of the whole Crimea crisis with all of their implications and suggested causes represent two different cultural models of the Crimea crisis that have risen from two different interpretative frameworks. However, by referring to these interpretations as cultural models, I will rely on a distinction between cultural models and cultural schemas, as it is defined by Bojan Žikić. The author argues that these "mental structures used to interpret the world" (Žikić 2008: 128) exist either as cultural schemas which "act as simple models in that sense that they represent a certain object or event" or as cultural models which "consist of interconnected elements, put together in such a way that they represent something" (Žikić 2008: 128). The latter thus also allow those elements to be complex in themselves - that is, cultural models can be and most often are comprised of cultural schemas of lower complexity (Žikić 2008: 128-129; Strauss, Quinn 1997; Olson 2005).

In this specific case, that would mean that cultural models of Crimea crisis are comprised of various other cultural schemas, such as those related to the ideas of a country as such, its borders or sovereignty, international law, and other concepts defining the important elements of the event. However, for the sake of clarity, I will refer to these complex cultural models comprised of cultural schemas as interpretations or "interpretative models" - interpretative because they offer an interpretation of social reality, and models because just like cultural models, they consist of interlinked networks (Strauss, Quinn 1997: 53), they are mental structures that organise "related pieces of our knowledge" in a certain way (Strauss, Quinn 1997: 49) and are "well-learned, but flexibly adaptive" (Strauss, Quinn 1997: 53).

These competing interpretations of the Crimea crisis are at same time the basis of what we can call the Crimea crisis "intertext". Intertext is a term used to denote the fact that "all utterances are in dialogue with prior utterances on the same subject, as well as with utterances yet to come" (Brockmeier 2005: 433). While 
intertextuality has been identified as "quality of all discourses" implying that each narrative exists at a place of intersection of other narratives (Brockmeier 2005), the dialogue between those two interpretations mainly consists of marking the opposing one as fake, unfounded or plain wrong. As a consequence, each interpretation is asking the audience to simply accept it, while denouncing all the others, thus assuming the position of a narrative that cannot be questioned and that is simply stating what might be called an objective truth - or at least what aims to gain the title of objective truth.

At the same time, this doesn't mean that each of the interpretations isn't in a much more "positive" dialogue with other texts. I would argue that this is so exactly because of the secondary meanings which are written into the Crimea crisis. For example, Russian officials on numerous occasions talked about "NATO expansion to the east" in the context of events in Ukraine, even though these statements are not brought into direct connection with the Crimea crisis. ${ }^{32}$ Or, on the other side, NATO officials referred to the Crimea crisis in order to justify the strengthening of the eastern flank of the alliance, especially in the Baltic region. ${ }^{33}$ So, both interpretations of the Crimea crisis are in constant dialogue with other texts that are related to the interpretation of international position, goals and foreign policy of the sides directly or indirectly involved in the Crimea crisis.

These secondary meanings and sub-narratives are directly tied to the interpretations of a certain event that is, at least technically, limited in its span. Some of them are related to what is perceived as the cause of the chain of events leading up to the crisis, and some of them are related to what is presented as consequences and further implication of those events. However, all of them allow the Crimea crisis to become even more separated from the "real" situation on the ground and more connected to the communication of a much broader view of global politics and international relations.

As such, the narrative of the crisis which follows a chronologically ordered sequence of events seems to collapse in a structure where each of the elements, each of the episodes, or cultural schemas of lower complexity becomes partially reflected in others. As a consequence, the interpretative models, comprised of interconnected cultural schemes seems to be analogue in its form and in its function to the structuralist understanding of a myth as a permanent structure that simultaneously conceptualise past, present and the future, and that has the function of cultural systematisation and orientation (Lévi-Strauss 1977; Nedeljković 2006).

If we pursue these myth-like properties of the Crimea crisis interpretations, we can also conclude that their constituent elements function as "partial metaphoric transformations" of each other (Leach 1976: 25) just as is the case with constituent episodes of a myth. The meaning of a myth can be read from its structure viewed

32 https://www.foreignaffairs.com/articles/ukraine/2016-04-18/why-putin-took-crimea (access: 13.02.2019).

${ }^{33}$ https://www.foreignaffairs.com/articles/baltics/2014-04-17/nato-after-crimea (access: 13.02.2019). 
as a "palimpsest of superimposed (but incomplete) metaphoric transformations" (Leach 1976: 25) just like the meaning of either interpretation of the crisis can be read only from the interconnectedness of its constituent cultural schemas.

In other words, identically to structuralist understanding of myth, interpretative models such as those representing the Crimea crisis aim to "tell a story" which can become "separated from its linguistic basis" and whose meaning is dependent on the way the individual elements, in this case the cultural schemas are related to each other (Lévi-Strauss 1977: 218-219). This story, in turn, acts as a "universal, long-lasting and standardised way of perceiving, constructing, remembering and sharing discourse" (Nedeljković 2006: 6) and as such, it plays a crucial role in shaping interpretations of the social reality and our activities within it.

With all these models of the second order, or "episodes" in terminology closer to structuralism, existing as partial metaphorical transformations of each other, the final reading of the interpretative model as a whole will, just as it is the case with myths, depend on the transformation of metonymic relations into metaphorical relations (Leach 1976: 25). For example, the American judgement of the legality of Russian activity in Crimea is in a metonymic relation with American judgement of Russia's international position as both these judgements are elements of the broader interpretative model of the crisis as a whole and thus exist in the same context. However, the activity of Russia in Crimea can also be presented as a metaphorical expression of Russia's foreign policy - if Crimea was annexed, then Russia is expansionist power; if Russia is expansionist power, then Crimea must have been annexed.

This presents the main challenge, but also the main modus operandi of "cultural operations" - using the cultural meanings and identities already present within a given context to create new interpretative models or new "myths" describing various events, situations or, as we will see, persons, and to shape these descriptions or interpretations in such a way that they can mobilise the public and accomplish various strategic and usually political goals. At the same time, operations of this kind will try to communicate those models in such a way that they are easily "internalised". The transformations of metonymic into metaphoric relations characteristic to the structure of myths are one of the keys to the success of this process as they allow certain statements, certain judgements and certain perspectives to be presented and later perceived as the question of common sense.

With this in mind, it comes as no surprise that the most contested symbols and cultural schemas when it comes to Crimea crisis, but also to other geopolitically important events and their interpretative models, are exactly those which are widely accepted on a more or less global scale - sovereignty, freedom, legality and the very concept of basic human rights. All of these elements are included in both competing interpretative models of the Crimea crisis and all of these elements are intended to establish connection with the global audience, but also, and maybe even more importantly, to try and connect certain statements, judgements, goals 
and actions to these widely accepted ideas and values through the transformation of metonymy to metaphor. This is where the internal structure of the interpretative model comes into play as the meaning of any given interpretation will depend on the way that its constituent elements are connected - more specifically, which actors are on the side of sovereignty and freedom and which oppose it, who acted in line with the law and who broke it, but equally important, who is morally right and who is not.

\section{Engaging the public: The circulation of interpretative models in a sociocultural context}

While the primary communication of the interpretations of the Crimea crisis considered here was undertaken by the relevant NATO and Russia officials and representatives, these interpretations circled the globe through mass media and were widely discussed, debated, used and reused throughout the cyberscape, that is, through the internet. So, the conflict between these two opposing interpretations of the crisis moved to digital media outlets, but also different groups on social media, where individuals took their stance, discussing and debating the official narratives, but also fusing them with new meanings and implications, depending on the nature, interests, identities and values of individuals or groups acting as secondary communicators.

It might be important to note that various political actors recognised the importance of internet communication in this sense, as exemplified by Mark Zuckerberg's five-hour long testimony to the US congress or various political initiatives and steps undertaken in the US, $\mathrm{EU}^{34}$ and Russia ${ }^{35}$ aimed at curbing so-called fake news and internet "disinformation" in general. With some of the major international players paying special attention to interaction on the internet in the domain of political, we can easily hypothesise that these activities in the cyberscape can have very noticeable effects on the "offline politics".

Of course, the importance of internet and its characteristic forms is nothing new - not only were digital technologies instrumental in numerous social movements all over the globe, but their efficiency in creating group identity has been known to the social scientists for quite some time. Gabriela Coleman argues that whenever individuals and groups communicate through the digital media, there will be circulations, reimaginings, magnifications, deletions, revisions and remakings of various cultural representations, experiences and identities, eventually resulting in "engendering of new collectives" (Coleman 2010: 488). For some, these "digital collectives" can be based on profession, but for most "average" internet

\footnotetext{
${ }^{34}$ https://ec.europa.eu/digital-single-market/en/fake-news-disinformation (access: 18.02.2019).

35 http://tass.com/society/1038921 (access: 18.02.2019).
} 
users, the internet is not directly related to work (Bakardjieva 2005: 69), functioning instead as "a space of leisure" (Spracklen 2015: 11).

Understanding of the internet as "a space of leisure", especially in the context of so-called Web 2.0 which denotes increased focus of the internet on user-generated content which serves to communicate and create individual and collective identity (Žakula 2012: 46, 48), as well as move from anonymous to more personalised internet with ever-increasing blurring of boundaries between "online" and "offline" identities (Žakula 2012: 47), is very important here. The possibility of the user to use internet in his or her free time in order to discover new symbolic worlds, but also take part in creating new ones can allow us to view the internet as a liminoid phenomenon, in the terminology of Victor Turner (Turner 1992). Being and acting online then becomes a form of leisure during which the users can "play" with the familiar, with novelty emerging from "unprecedented combinations of the familiar elements" (Turner 1992: 27).

If the creation of these symbolic worlds is a group endeavour then the line between this process and the "engendering of new collectives" that Coleman writes about becomes rather unclear. The sense of group identity and group cohesion, as well as distinction to others is inherently tied to the clusters of symbols that are used by the group to produce and utilise the representations and the descriptions of themselves in order to differentiate between the cultural system of the group and the wider environment that system is surrounded by (Luman 2001: 44). This is where the complex interpretative models, narratives similar to myths come into play, providing the "resources" for cultural creativity that results in the creation and maintenance of the opposition between "us" and "them", between symbolic world of the group and the social reality that surrounds it and that is perceived and described by it (Luman 2001).

At this point, it would be prudent to take a quick look at Korybko's understanding of psychological operations, more specifically, on his idea that they aim to "internalise" certain ideas, making the impression that they appeared spontaneously and authentically among the members of a given society or group (Korybko 2015: 35). If the internet and interaction that takes place through it really contribute to the formation of new collectives as literature discussed above seems to suggest, then psychological operations can easily be directed at those collectives too. And even more importantly, when certain interpretative models, like those related to the Crimea crisis discussed before, become present in those groups, they can in some instances become closely associated to those representations used to differentiate between the social world of a group and its wider environment.

In the context of Web 2.0 marked by the blurring of lines between online and offline identities (Žakula 2012: 47) this means that these same cultural meanings and models can be "transported" into the offline reality. And, what's more, as they are primarily encountered in the leisure space work of the internet, I would argue, they are that much more likely to be combined with other elements of importance to individual and collective identities of various kinds. 
So, I would argue that complex interpretative models can become closely associated with the individual and collective identities present among certain audiences. And as they are encountered in the sphere of the liminoid, they can much more easily be brought into relation with other elements that are not directly related to the phenomenon that said interpretative model describes. In the liminoid space of the internet, these models will be used and re-used, combined with other elements, shared and communicated in their modified forms - in other words, their further modifications will begin circulating in various sociocultural contexts, reaching an ever-greater number of people and getting bound to value systems and identities, thus prompting individuals to act and to get emotionally engaged.

For example, let's take a look at the website called Prop or $\mathrm{Not}^{36}$ which welcomes the visitor with the message: "Russia is manipulating US public opinion - we are trying to stop it". While focusing on the idea of unbiased journalism, the community behind the website claims that Russian interpretation of the events on Crimea ignores the viewpoints of Ukrainians as well as Tatars on the peninsula. Throughout the website, the authors refer to the crisis as "Russian occupation" or "annexation", but with the main focus being on the skewing of truth and the activities of so-called "Russian trolls" who spread disinformation online. As such, this website invites the readers to take part in fight for real news and objective truth thus simultaneously lending support to "annexation interpretation" and discrediting the "reunification interpretation". On the other hand, we can mention Simon Shuster's article titled "Crimea's Gay Community Moves Out as Russian Homophobia Sets In" ${ }^{37}$ which analyses the problems faced by the LGBT community in Crimea, while at the same time bringing them into connection with what seems to be a form of institutionalised homophobia that spread to Crimea following the "annexation" of the peninsula. In this instance, the "annexation interpretation" is brought into direct connection with what is perceived as homophobic stance of the Russian state - which is something that is completely absent in the primary interpretation, but which adds to it a completely new layer of meaning.

However, we can gain a much more diverse insight into ways that, for example, ideas of civil liberties or multiculturalism are fused together with "annexation interpretation" of the Crimea crisis if we take a look at some of the informal groups on social media that are organised around this issue. Facebook groups called Crimea_SOS and Liberate Crimea are examples of those digital collectives which directly discuss the issue of Crimea crisis, while many more, such as $E U$ vs Disinformation which have a broader scope, but whose members have talked about Crimea crisis in the context of Russian threat for civil liberties and liberal values.

But, the supporters of the "reunification interpretation" proved to be just as skilful as finding ways to broaden their reach. A very theatrically titled article "Vladimir Putin: Resistance Fighter Against Imperialism, Saviour of Syria, and

${ }^{36} \mathrm{http}: / /$ www.propornot.com/p/home.html (access: 18.02.2019).

${ }^{37} \mathrm{http}: / /$ time.com/3482205/crimea-gay-community-flees-russian-homophobia/(access: 16.02.2019). 
Beacon of Hope" 38 although not directly related to the issue of Crimea perfectly exemplifies the way that "reunification interpretation" is presented in various Facebook groups including Vladimir Putin - A Fighter and Strategist against Imperialism, With Russia in Heart or Support Putin - Support Russia.

These digital communities view Russia's actions in Crimea not only as in line with the international law, but also as important steps in the fight against what is perceived as hegemony or imperialism of the United States, NATO, European Union, or other political actors. Another very interesting example is a group named Crimea is Russia, Kosovo is Serbia, Karabakh is Armenia, Cyprus is Greece. The very title of this group shows another way that "reunification interpretation" is communicated to the specific audiences. Namely, the title mentions a number of countries which have disputed regions - and more specifically, countries that have important historic and religious connections with Russia.

Once a certain interpretation is "integrated" into a certain symbolic world, the ideas and values that the interpretation communicates also become part of a given symbolic world, allowing them to be perceived as spontaneous and authentic and not communicated from the "outside". In other words, and closer to Lumann's understanding of social systems, they become perceived and represented as inner elements of a cultural system rather than something that exists in the broader environment.

But, in order for any complex interpretative model to circulate in a given sociocultural context, that model needs to be "understandable" to the audience and to be open for the ascription of cultural meanings (Žikić 2012: 316), meaning that the audience needs to be able to decode messages communicated through any given interpretative model. But the model also needs to be open for the audience to ascribe additional meanings to it, thus binding it to various subcultural or collective identities, making them essentially something that matters, something that can express meanings that transcend purely political.

If the internet can truly be viewed as a liminoid space, then it can certainly serve as a context in which these re-combinations can take place. However, this also means that complex interpretative models such as those discussed will have to "survive" integration and interpretation in numerous symbolic worlds with the end result of that process being unpredictable with absolute certainty. In some cultural operations, the models of this kind will be shaped in such a way that they target specific groups, specific sociocultural contexts and specific symbolic worlds, while in others they might be directed as a population as a whole. Making these decisions and shaping the interpretative models accordingly thus becomes another primary challenge of those people tasked with "engineering consent" as Korybko would say or - as I would argue - tasked with conducting instances of

38 https://www.sott.net/article/372855-Vladimir-Putin-Resistance-Fighter-Against-ImperialismSavior-of-Syria-and-Beacon-of-Hope (access: 16.02.2019). 
strategic cultural communication that aim to offer people a specific worldview that is capable to engage them and mobilise them politically if the need arises.

However, at this point, it would seem that there is still one instance where the term psychological operations seems more appropriate than the suggested term cultural operations. It is, of course, the question of emotional engagement of an individual. However, this might not necessarily be the case. If we accept the constructivist position on the question of emotions, we can claim that emotions, cognition and perception are indistinguishable processes within the human mind (Christensen 2018; Munck de 2013). In a manner similar to this, John Leavitt argues that emotions are "meaning/feeling experiences" which are organised and mediated through systems of signs (Leavitt 1996: 530).

Just like meanings, Leavitt writes, emotions too are socially and culturally shared, they are communicated among groups and individuals and they are a part of the cultural knowledge an individual acquires by living in a certain sociocultural context and that is founded on affective associations, analogue to semantic associations (Leavitt 1996: 527). What this means is that people living within the same sociocultural context will have high chances of feeling the same emotions in same situations or during exposure to certain symbols and phenomena. And in line with this, various interpretative models, not just those employed in hybrid warfare, can also be emotionally engaging for all people sharing the same exposure to a cluster of cultural elements.

In the examples mentioned above, it would mean that certain people will become highly emotionally engaged when presented with arguments of homophobic policies, attacks on the free press, distortions of truth or violations of civil liberties conducted by the Russian federation. Just like other people will become equally emotionally engaged when faced with arguments of imperialist and hegemonic tendencies of certain international actors or reminded about their own lost historic territories with the promise of the possibility of their rightful "return home".

\section{Conclusion}

In this article, I have presented a way to rethink the concept of hybrid warfare within the framework of semiotic anthropology. Starting from the premise that so-called "psychological operations" can be better described as cultural operations, I have showed that these activities are primarily related not to psychological categories, but to cultural meanings, values, identities and worldviews. Using Leach's concept of cultural communication, I have argued that so-called strategic communication can be viewed as complex cultural communication which is tasked with communicating a certain interpretation of a social reality.

In order to better define the structure of these interpretations, I relied on the theory of cognitive schemas developed by Claudia Strauss and Naomi Quinn and 
understanding of cognitive models developed by Bojan Žikić. The former theory posits that cultural schemas consist of networks of elements, while the latter claims that they can exist in various levels of complexity - as cultural schemas which act as simple models representing something and as cultural models which consist of interconnected elements brought together in such a way that they represent something. I have argued that constituent elements of complex cultural models which I referred to as interpretative models are akin to individual "episodes" of the myth, according to structuralist analysis of the said phenomenon. Consequently, it was possible to conclude that just like myths, and in line with some of the central postulates of semiotic anthropology, these complex narrative structures function as tools for understanding, perceiving and acting within social reality. As such, they are very powerful in shaping not only interpretations of given events, but also reactions to them.

Finally, by relying on Leavitt's theory of affective associations, I was able to show how these narrative structures can engage certain people and cause certain emotions in them, thus further shaping their experience and their behaviour in relation to these models. In order for them to be effective at that, however, they need to be brought into relation with certain values, meanings and identities. This same process, as I have argued, also allows for the ideas communicated in this way to be perceived as spontaneous and authentic. But, in order for that relation to be established, the said structures have to be opened for ascription of cultural meanings and to facilitate certain cultural reception. I have argued that the internet as leisure space and liminoid phenomenon represents a highly suitable context for re-combination of elements which will result in successful ascription of additional meanings and values relevant for certain identities.

I have explored these ideas by comparing two different interpretations of the Crimea crisis and its subsequent change of status, after it has been incorporated into the Russian Federation. On one hand, I mentioned the narrative put forward by Russian officials that insists that this process was lawful reunification, and on the other, narrative put forward by various NATO officials who instead insist that the process is illegal annexation and occupation. I have first explored the way that that these interpretations are formulated and then showed how they have been brought into relation with various meanings, values and identities not present in the "official" interpretations of the Crisis in such a way that they can emotionally engage individuals and groups.

Finally, the central goal of this text was to offer a new understanding of hybrid warfare that would define this term as a conflict resulting from the simultaneous presence of several, usually two competing interpretations of social reality within one sociocultural context. I would argue that this approach has several benefits.

Firstly, by focusing on interpretations of social reality, we could more precisely define the methods of hybrid warfare as cultural, as opposed to psychological. Secondly, this would also allow us to explore different cultural models used to describe and interpret certain events as well as meanings of those interpretations 
without the need to give any kind of a judgement regarding the event that is being interpreted. Finally, by viewing hybrid warfare as simultaneous presence of competing worldviews, we eliminate the need to differentiate between the attackers and defenders, which in turn allows us to simply focus on exploring these complex forms of symbolic behaviour which seem to play an ever-increasing role in the political conflicts of the $21^{\text {st }}$ century.

\section{Bibliography}

Bakardjieva $\mathrm{M}$.

2005 Internet Society: The Internet in Everyday Life, London.

Baudrillard J.

1995 The Gulf War did not Take Place, Indianapolis.

Brockmeier J.

2005 The Text of the Mind, in: The Mind as a Scientific Object, ed. C.E. Erneling, D.M. Johnson, Oxford, p. 432-447.

Burgers T., Romaniuk S.

2016 Hybrid Warfare in the South China Sea: The United States' Little Grey (Un)Men, https://thediplomat.com/2016/12/hybrid-warfare-in-the-south-china-sea-the-united-states-little-grey-unmen/ (access: 16. 11. 2018).

Christensen J.

2018 Sound and the Aesthetics of Play: A Musical Onthology of Constructed Emotions, Aalborg.

Coleman G.

2010 Ethnographic Approaches to Digital Media, "Annual Review of Anthropology", no. 39 , p. $487-509$.

Geertz C.

2000 Interpretation of Cultures, New York.

Hoffman F.

2014 On Not-So-New Warfare: Political Warfare vs. Hybrid Threats, http://warontherocks.com/2014/07/on-not-so-new-warfare-political-warfare-vs hybridthreats/ (access: 16.11.2018).

Kofman M., McDermot R.

2015 No Return to Cold War in Russia's New Military Doctrine, http://www.eurasiareview.com/03022015-no-return-cold-war-russias-new-military-doctrine-analysis/ (access: 16.11.2018).

Kofman M., Rojansky M.

2015 A Closer Look at Russia's "Hybrid War", "Kennan Cable", no. 7, p. 1-8.

Korybko A.

2015 Hybrid Wars: The Indirect Adaptive Approach to Regime Change, Moscow.

Leach E.

1976 Culture and Communication: The Logic by Which Symbols are Connected, Cambridge.

Leavitt J.

1996 Meaning and Feeling in the Anthropology of Emotions, "American Ethnologist", no. 23 , p. $514-539$. 
Lévi-Strauss C.

1977 Strukturalna antropologija, transl. I. Kuvačić, Zagreb.

Luman N.

2001 Društveni sistemi: osnovi opšte teorije, transl. L. Topić, Novi Sad.

Mattis J., Hoffman F.

2005 Future Warfare: The Rise of Hybrid Wars, https://www.usni.org/magazines/proceedings/2005-11/future-warfare-rise-hybrid-wars (access: 16.11.2018).

Munck V. de

2013 A Theory Explaining the Functional Linkage between the Self, Identity and Cultural Models, "Journal of Cognition and Culture", no. 13, p. 179-200.

Nedeljković S.

2006 Mit, religija i nacionalni identitet: mitologizacija u Srbiji u periodu nacionalne krize, „Etnoantropološki problemi”, no. 1, p. 155-180.

Newson R.

2014 Counter-Unconventional Warfare Is the Way of the Future: How Can We Get There?, http://smallwarsjournal.com/blog/counter-unconventional-warfare-is-the-way-of-the-future-how-can-we-get-there (access: 16.11.2018).

Obućina V.

2016 Što je hibridno ratovanje i kako se Rusija snalazi u njemu?, http://www.advance.hr/vijesti/sto-je-hibridno-ratovanje-i-kako-se-rusija-snalazi-u-njemu/ (access: 7.5.2016).

Olson D.

2005 Mind, Brain and Culture, in: The Mind as a Scientific Object, ed. C.E. Erneling, D.M. Johnson, Oxford, p. 160-165.

Spracklen K.

2015 Digital Leisure: The Internet and the Popular Culture, Basingstoke.

Strauss C., Quinn N.

1997 A Cognitive Theory of Cultural Meaning, Cambridge.

Turner V.

1992 From Ritual to Theatre: The Human Seriousness of Play, London.

Zlatohlávek P.

2016 Hybrid Warfare: A New Phenomenon in Europe's Security Environment, http:// data.idnes.cz/soubory/na_knihovna/A161212_M02_029_HH16_PP-EN-V1.PDF (access: 16.11.2018).

Žakula S.

2012 Da li kiborzi sanjaju biomehaničke ovce? Telo i hiperrealnosti, „Antropologija”, Žikić B. no. 12 , p. $43-61$.

2008 Kako složiti babe, žabe i električne gitare: uvod u kognitivnu antropologiju, „Antropologija“, no. 6, p. 117-139.

2010 Antropologija i žanr: naučna fantastika - komunikacija identiteta, „Etnoantropološki problemi”, no. 5, p. 17-34.

2012 Popularna kultura, nadkulturna komunikacija, „Etnoantropološki problemi”, no. 7, p. 315-341. 


\section{Sources}

https://www.rt.com/news/crimea-facts-protests-politics-945/ (access: 16.11.2018). https://www.rt.com/news/crimea-defense-russian-soldiers-108/ (access: 16.11.2018). https://www.rt.com/news/putin-address-parliament-crimea-562/ (access: 16.11.2018). https://www.rt.com/news/russia-troops-ukraine-possible-359/ (access: 16.11.2018). https://www.rt.com/news/crimea-vote-join-russia-210/ (access: 16.11.2018).

https://www.rt.com/news/international-observers-crimea-referendum-190/ (access:

16.11.2018).

https://www.rt.com/news/russia-parliament-crimea-ratification-293/(access: 16.11.2018). https://www.rt.com/news/schmidt-crimea-russia-germany-465/ (access: 16.11.2018). http://edition.cnn.com/2014/03/18/world/europe/ukraine-crisis/index.html(access:16.11.2018). http:/edition.cnn.com/2014/03/12/world/europe/ukraine-crisis/index.html (access: 16.11.2018).

https://edition.cnn.com/2014/03/19/world/europe/crimea-points-and-counterpoints/index.html (access: 16.11.2018).

https://edition.cnn.com/2014/03/17/world/europe/ukraine-vote-legality/index.html (access: 16.11.2018).

https:/edition.cnn.com/2014/03/20/world/europe/ukraine-crisis/index.html (access: 16.11.2018). https://edition.cnn.com/2014/04/08/opinion/crimea-putinland-ukraine-andrey-kurkov/ index.html (access: 16.11.2018).

http://www.mid.ru/en/foreign_policy/news/-/asset_publisher/cKNonkJE02Bw/content/

$\mathrm{id} / 671172$ (access: 16.02.2019).

https://www.nato.int/cps/en/natohq/news_118114.htm (access: 16.02.2019).

https://www.nato.int/cps/en/natohq/opinions_115313.htm (access: 16.02.2019).

https://www.foreignaffairs.com/articles/baltics/2014-04-17/nato-after-crimea (access: 13.02.2019).

https://foreignpolicy.com/2014/03/18/wheres-natos-strong-response-to-russias-invasion-of-crimea/ (access: 13.02.2019).

https://www.theguardian.com/world/2014/mar/06/hillary-clinton-says-vladimir-putinscrimea-occupation-echoes-hitler (access: 14.02.2019).

https://www.usatoday.com/story/news/world/2014/03/25/ukraine-europe/6863413/ (access: 16.02.2019).

https://www.usatoday.com/story/theoval/2014/03/02/obama-russia-putin-ukrainecrimea/5944265/ (access: 16.02.2019).

http://time.com/13902/barack-obama-ukraine-russia/ (access: 14.02.2019).

https://www.theguardian.com/world/2014/jul/29/economic-sanctions-russia-eu-governments (access: 14.02.2019).

https://www.usatoday.com/story/news/politics/2014/03/20/obama-ukraine-statement/6647657/ (access: 16.02.2019).

https://www.theguardian.com/commentisfree/2014/apr/30/russia-ukraine-war-kievconflict (access: 16.02.2019).

https://themoscowtimes.com/articles/g7-leaders-agree-to-prolong-anti-russian-sanctions-53043 (access: 16.02.2019).

https://www.sott.net/article/372855-Vladimir-Putin-Resistance-Fighter-AgainstImperialism-Savior-of-Syria-and-Beacon-of-Hope (access: 16.02.2019). 
https://www.reuters.com/article/us-ukraine-crisis-nato/nato-says-crimea-referendumwould-break-international-law-idUSBREA2D1NI20140314 (access: 18.02.2019). https://sputniknews.com/russia/201412181015985110/ (access: 16.02.2019). https://sputniknews.com/politics/201412201016050415/ (access: 16.02.2019). http://tass.com/world/799886 (access: 14.02.2019). https://sputniknews.com/business/201607101042736754-france-sanctions-losses/ (access: 14.02.2019).

http://tass.com/world/800230 (access: 18.02.2019).

https://www.rt.com/news/putin-statement-ukraine-russia-743/ (access: 13.02.2019). https://sputniknews.com/europe/201503181019648159/ (access: 18.02.2019). https://www.reuters.com/article/us-ukraine-crisis-russia-lavrov/russias-lavrov-says-noagreement-with-kerry-on-ukraine-report-idUSBREA2515V20140306 (access: 18.02.2019). http://tass.com/russia/792788 (access: 16.02.2019).

https://www.rferl.org/a/medvedev-warns-that-u-s-sanctions-banning-banks-currency-use-would-be-economic-war-/29425557.html (access: 14.02.2019).

https://www.foreignaffairs.com/articles/ukraine/2016-04-18/why-putin-took-crimea (access: 13.02 .2019$)$.

http://www.propornot.com/p/home.html (access: 18.02.2019).

http://time.com/3482205/crimea-gay-community-flees-russian-homophobia/ (access: 16.02.2019).

https://sputniknews.com/politics/201510291029308926-crimea-moscow-zakharova-fabius/ (access: 16.02.2019).

https://ec.europa.eu/digital-single-market/en/fake-news-disinformation/ (access: 18.02.2019). http://tass.com/society/1038921/ (access: 18.02.2019). 